\title{
A Cellulose-Supported DNA-Based Ligand for Asymmetric Catalysis
}

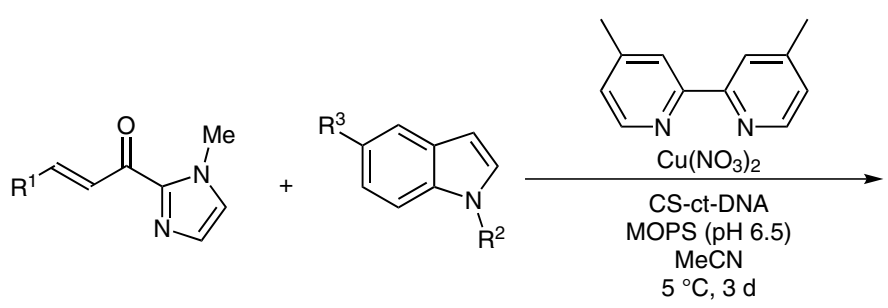<smiles>[R]C(CC(=O)c1nccn1C)c1c[nH]c2ccc([Tl])cc12</smiles>

$\mathrm{R}^{1}=\mathrm{Me}, \mathrm{R}^{3}=\mathrm{OMe}>99 \%$ conversion, $81 \%$ ee $(\mathbf{A})$ $\mathrm{R}^{1}=\mathrm{Me}, \mathrm{R}^{3}=\mathrm{Cl}>99 \%$ conversion, $73 \%$ ee $\mathrm{R}^{1}=\mathrm{Me}, \mathrm{R}^{3}=\mathrm{Br} 96 \%$ conversion, $66 \%$ ee $\mathrm{R}^{1}=n-\mathrm{Pr}, \mathrm{R}^{3}=\mathrm{OMe}>99 \%$ conversion, $83 \%$ ee

$\mathrm{R}^{1}=n-$ Pent, $\mathrm{R}^{3}=\mathrm{OMe}>99 \%$ conversion, $73 \%$ ee<smiles>[X]c1ccc(C(CC(=O)c2nccn2C)c2c[nH]c3ccc(OC)cc23)cc1</smiles>

$\mathrm{X}=\mathrm{H}>99 \%$ conversion, $62 \%$ ee $\mathrm{X}=\mathrm{OMe} 80 \%$ conversion, $54 \%$ ee $\mathrm{X}=\mathrm{Cl}>99 \%$ conversion, $50 \%$ ee $\mathrm{R}^{1}=\mathrm{C}_{6} \mathrm{H}_{5}>99 \%$ conversion, $76 \%$ ee $\mathrm{R}^{1}=2-\mathrm{BrC}_{6} \mathrm{H}_{4} 25 \%$ conversion, $65 \%$ ee<smiles>[R]C(CC(=O)c1nccn1C)c1cn(C)c2ccc(OC)cc12</smiles><smiles>[R]C(CC(=O)c1nccn1C)c1cn([R])c2ccc([Tl])cc12</smiles>

\section{Gategory}

Polymer-Supported Synthesis

\section{Key words}

\section{DNA}

asymmetric catalysis

Friedel-Crafts alkylation

Michael addition

copper

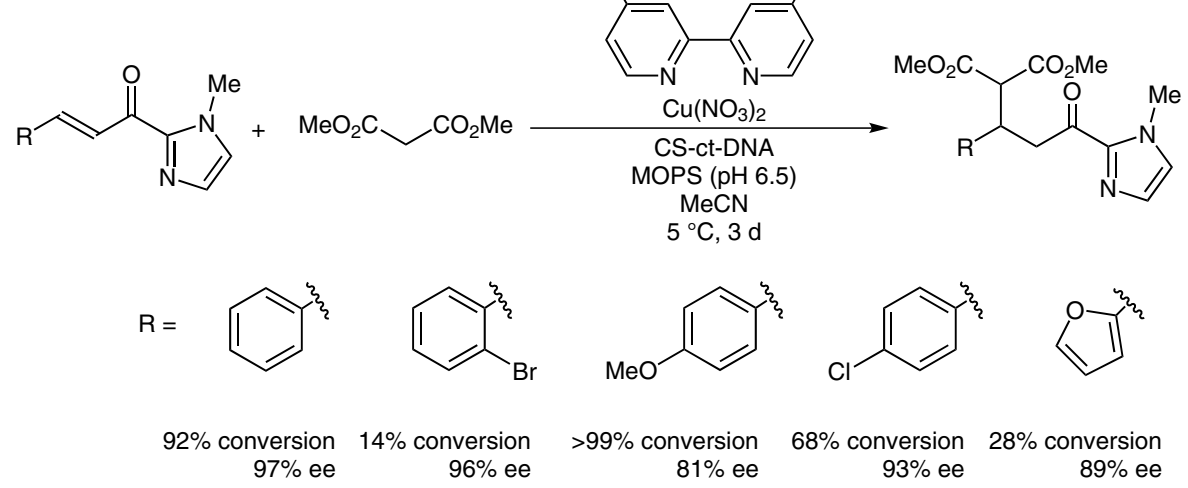

Significance: Copper-catalyzed asymmetric Friedel-Crafts alkylations (eq. 1) and Michael additions (eq. 2) proceeded in the presence of cellulose-supported calf thymus DNA and 4,4'-dimethyl-2,2'-bipyridine (dmbpy) to give the corresponding alkylation products with up to >99\% conversion and up to $97 \%$ ee.

SYNFACTS Contributors: Yasuhiro Uozumi, Kotaro Yamamura Synfacts 2015, 11(7), 0773 Published online: 17.06.2015 Dol: 10.1055/s-0034-1380997; Reg-No.: Y06715SF
Comment: In the formation of compound $\mathbf{A}$, the catalyst was recovered and reused nine times without adding any copper or dmbpy. Compound A was also prepared in 96\% conversion and up to $80 \%$ ee by a continuous-flow process using the DNA-based catalyst packed in a medium-pressure liquid chromatography cartridge (residence time: $38 \mathrm{~min}$, room temperature). 